\title{
The response of Opalinus Clay when exposed to cyclic relative humidity variations
}

\author{
Katrin M. Wild, Patric Walter, and Florian Amann \\ Department of Earth Sciences, Geological Institute, ETH Zurich, 8092 Zurich, Switzerland \\ Correspondence to: Florian Amann (florian.amann@erdw.ethz.ch)
}

Received: 13 December 2016 - Discussion started: 14 December 2016

Revised: 1 March 2017 - Accepted: 6 March 2017 - Published: 30 March 2017

\begin{abstract}
Clay shale specimens were exposed to cyclic relative humidity $(\mathrm{RH})$ variations to investigate the response of the material to natural environmental changes. Opalinus Clay, a clay shale chosen as host rock for nuclear waste disposal in Switzerland, was utilized. The specimens were exposed to stepwise relative humidity cycles in which they were alternately allowed to equilibrate at 66 and $93 \%$ relative humidity. Principal strains were monitored throughout the experiments using strain gauges. After each relative humidity cycle, Brazilian tensile strength tests were performed to identify possible changes in tensile strength due to environmental degradation.

Results showed that Opalinus Clay follows a cyclic swelling-shrinkage behaviour with irreversible expansion limited to the direction normal to bedding, suggesting that internal damage is restricted along the bedding planes. The Brazilian tensile strength in direction parallel and normal to bedding as well as the water retention characteristic remained unaffected by the RH variations.
\end{abstract}

\section{Introduction}

In Switzerland, Opalinus Clay, a Mesozoic shale formation of about $180 \mathrm{My}$ in age, has been selected as the host rock for the disposal of high-level nuclear waste (BFE, 2011). Opalinus Clay features several beneficial properties such as its low permeability, the high radionuclide retention, and the potential for self-sealing. However, the favourable characteristics of the rock mass may change during tunnel excavation. Excavation is accompanied by stress redistribution and the development of an excavation damage zone (EDZ). The evolution of the EDZ is an important factor for the long-term safety of a nuclear repository as it may significantly influence the permeability of the confining host rock and offer pathways for radionuclide transport. Unloading and/or exposure to atmospheric conditions with a low relative humidity $(\mathrm{RH})$ may lead to suction and, if the air-entry value is exceeded, to desaturation of the rock mass close to the tunnel. These processes can lead to shrinkage and the formation of desiccation cracks (Tsang et al., 2012). During the open-drift stage of a nuclear repository, seasonal atmospheric changes, especially $\mathrm{RH}$ variations, may alter the rock mass and influence the long-term crack evolution. Möri et al. (2010) measured crack apertures of Opalinus Clay in the framework of the cyclic deformation (CD) experiment at Mont Terri Underground Rock Laboratory (URL) located in the Jura Mountains, Switzerland. They found that the cracks close during summer (i.e. when the RH is high) and open during winter (i.e. when the RH is low). Crack closure and opening are associated with swelling and shrinkage of Opalinus Clay. Möri et al. (2010) also observed a net closure of the cracks over several seasonal cycles, which indicates an irreversible deformation component that is likely associated with timedependent processes such as consolidation, creep, or slaking. These irreversible deformation components can contribute to both tunnel convergence and self-sealing of the EDZ. The self-sealing effect is the ability of clay shales to close previously developed cracks and therefore reduce their permeability through hydro-mechanical, hydro-chemical, and/or hydro-biochemical processes (Bernier et al., 2007). Among others, the adsorption of water on clay minerals and related volumetric expansion can be associated with this effect.

Numerous studies have been conducted to show the influence of drying-wetting cycles on clay or clay shale specimens (e.g. Chu and Mou, 1973; Popescu, 1980; Chen and 
Ma, 1987; Osipov et al., 1987; Dif and Bluemel, 1991; Day, 1994; Al-Homoud et al., 1995; Basma et al., 1996; Pejon and Zuquette, 2002). In those studies, however, swelling was performed by allowing the specimens to fully soak in water. Few studies exist in which the influence of cycles in $\mathrm{RH}$ on the drying-swelling characteristics of clay shales has been investigated (e.g. Grice, 1968; Van Eeckhout, 1976; Olivier, 1979; Pham et al., 2007; Farulla et al., 2010; Cardoso et al., 2011; Yang et al., 2012; Pineda et al., 2014). Grice (1968) noted that specimens of Utica shale that were immersed in water disintegrated completely after oven drying. Specimens that were exposed to RH fluctuations between 60 and $90 \%$ for a period of 9 months, however, showed only minor cracking. Van Eeckhout (1976) equilibrated specimens of Beatrice coalmine shale to various levels of RH to study the mechanisms of reduction in rock strength resulting from variations in RH. During moisture absorption he measured a volumetric expansion in the order of $0.2-1 \%$. The strains were larger in direction normal to bedding and occurred mostly between 48 and $100 \%$ RH. Subsequent drying of the specimens to the initial level of RH showed that about $0.25 \%$ of the strains were not recoverable. Van Eeckhout (1976) identified these expansion-contraction characteristics and the associated lengthening in internal cracking as a possible cause for the lowering in strength he observed due to humidity fluctuations. Similar observations have been made by Olivier (1979) for specimens of a Lower Triassic mudrock. With the help of water retention curves for several wetting-drying cycles between 10 and $99 \%$ RH, Cardoso et al. (2011) showed that the air-entry value of an Upper Jurassic marl decreases with an increasing number of cycles. The decrease is accompanied by an increase in void ratio indicating a degradation of the material. Pham et al. (2007) subjected specimens of mudstones from Bure to one cycle of RH from 98 to $32 \%$ and back to $98 \%$. The measurement of strains as well as the ultrasonic velocity showed a hysteresis between drying and wetting curves. Additionally, a non-linearity has been observed as more strain was induced by a change in $\mathrm{RH}$ at high levels of RH (i.e. between 76 and $98 \%$ ) than for the same change at lower RH. Yang et al. (2012) used digital image correlation techniques to study the deformation behaviour of Callovo-Oxfordian argillaceous rock specimens subjected to axial load (between 0.3 and $8.5 \mathrm{MPa}$ ) and $\mathrm{RH}$ cycles (between 39 and $85 \%$ ). A linear relationship between $\mathrm{RH}$ and strain has been observed for RH smaller than $75 \%$. Furthermore, the strains were reversible during cycles of hydration and dehydration at low axial stress $(0.3$ and $2 \mathrm{MPa})$, whereas irreversible strains (i.e. a net shrinkage) have been measured for RH cycles at $8.5 \mathrm{MPa}$ axial load. Pineda et al. (2014) experimentally investigated the influence of RH cycles on the degradation of Lilla claystone in a long-term RH cycling experiment using ultrasonic wave velocity measurements and Brazilian tensile strength tests. The applied RH cycles caused an irreversible increase in the specimens' volumes as swelling always exceeded the amount of shrink- age. Pineda et al. (2014) found that higher peak-to-peak amplitudes in RH cycles (cycles between 20 and $99 \%$ were compared to cycles between 50 and $99 \%$ ) led to larger volumetric swelling. This effect was less pronounced for specimens that were tested under higher confinements. With the help of microstructural analyses, cracking has been identified as the main cause for irreversible swelling for Lilla claystone. Furthermore, the degradation of the material was manifested in a decrease in tensile strength from 2.9 to $0.2 \mathrm{MPa}$ after four cycles and a decrease in dynamic Young's modulus by more than $50 \%$. For both quantities, the reduction was largest for the first cycle; afterwards a decreasing degradation rate was observed.

All studies mentioned above showed that cyclic variations in RH can have a significant influence on rock mechanical parameters such as tensile strength and can lead to irreversible volume changes which might contribute to the destabilization of underground excavations but also favour processes that are considered to control self-sealing.

This study aims at contributing to the understanding of the influence of RH variations on the mechanical and hydromechanical behaviour of Opalinus Clay. A series of specimens were exposed to RH variations under unstressed conditions and tested for their Brazilian tensile strength. The study focuses on answering the question of whether Opalinus Clay shows a damage evolution when exposed to RH cycles that affects the tensile strength and causes irreversible volumetric expansion that might be relevant for long-term deformations and/or self-sealing.

\section{Tested material and experimental procedure}

\subsection{Material description}

For this study, samples from the shaly facies of Opalinus Clay from the Mont Terri URL, Switzerland, were used. The formation is part of the Mont Terri anticline that formed during the folding of the Jura Mountains. The present overburden at the URL lies between 230 and $330 \mathrm{~m}$ but is estimated to have reached up to $1350 \mathrm{~m}$ in the late Tertiary (Thury and Bossart, 1999; Mazurek et al., 2006). The shaly facies of Opalinus Clay contains a clay content of 50-80\% (Mazurek, 1998; Klinkenberg et al., 2009; Nagra, 2002; Bossart, 2005). The clay minerals can be subdivided into illite (15-25\%), illite-smectite mixed-layer phases (10-15\%), kaolinite (20$30 \%$ ), and chlorite (5-15\%). Beside the clay minerals, Opalinus Clay consists of quartz (10-20\%), feldspar (0-5\%), carbonates $(5-25 \%)$, pyrite $(0-3 \%)$, and organic material $(0-$ $1 \%)$. The clay particles are aligned sub-parallel to each other leading to a distinct macroscopic bedding. As a result, the physical properties of Opalinus Clay show a strong transversely isotropic behaviour. The hydraulic conductivity, for example, varies between $10^{-12} \mathrm{~m} \mathrm{~s}^{-1}$ parallel to bedding and $10^{-14} \mathrm{~m} \mathrm{~s}^{-1}$ normal to bedding (Marschall et al., 2004). The 


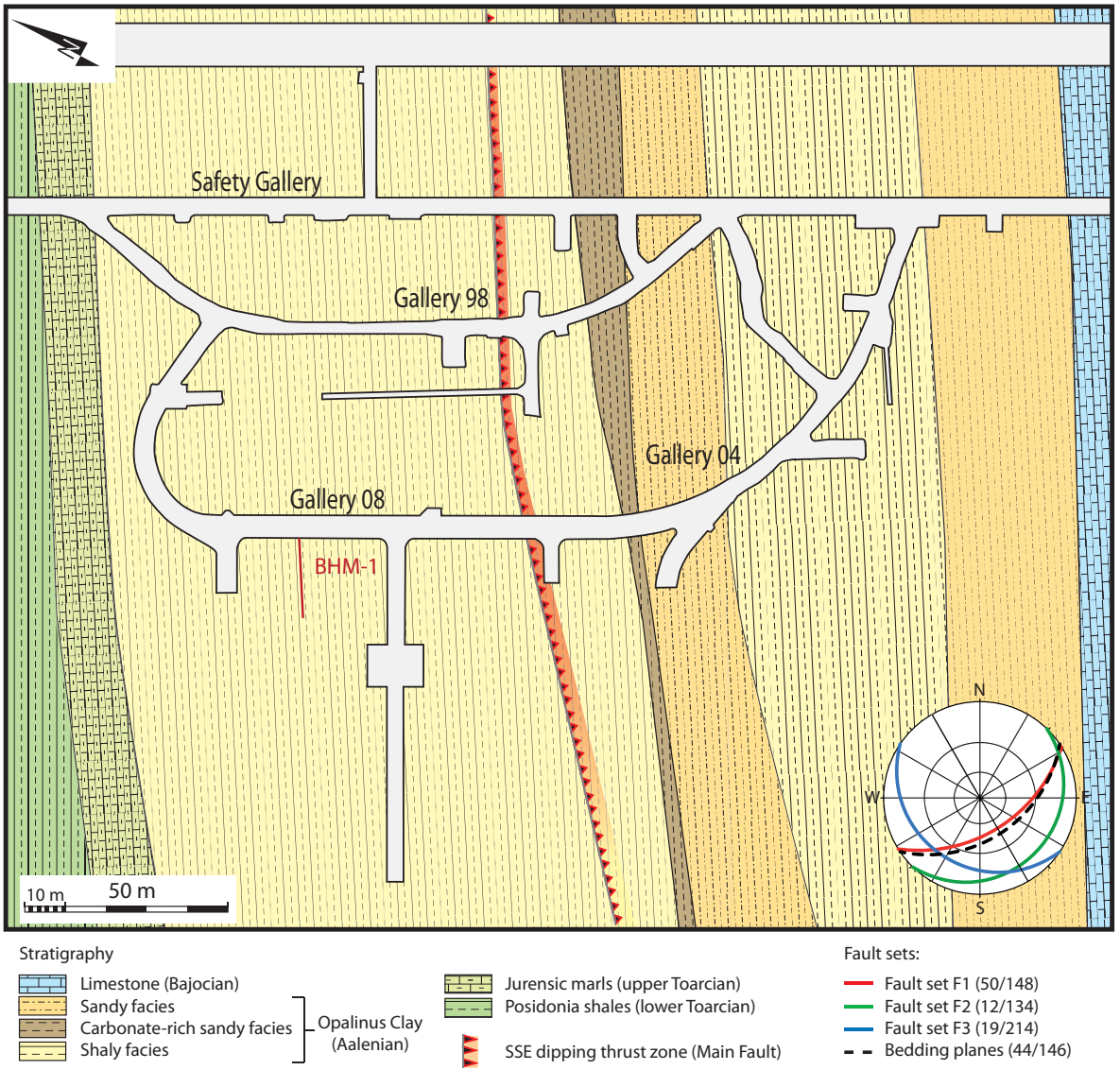

Figure 1. Geological map of the Mont Terri URL (modified from Nussbaum et al., 2011). The specimens used in this study were obtained from the borehole BHM-1 that was drilled parallel to bedding in Gallery 08. The location of the borehole is indicated approximately.

water loss porosity of the shaly facies is in the order of 15 $19 \%$ (Bossart, 2005; Amann et al., 2011, 2012; Wild et al., 2015; Wild, 2016). The pore water of the Opalinus Clay at the Mont Terri URL can be classified as $\mathrm{Na}-\mathrm{Cl}$ water and, with regard to its composition, is still close to that of the seawater where the material was deposited (Thury and Bossart, 1999; Pearson et al., 2003).

\subsection{Sampling and specimen preparation}

In total, 31 specimens were taken from two $67.5 \mathrm{~mm}$ diameter bore cores obtained from a $25 \mathrm{~m}$ long borehole (BHM-1) that was drilled in Gallery 08 in the shaly facies of Opalinus Clay at the Mont Terri URL (Fig. 1). A triple-tube core barrel with compressed air cooling was used. The bore axis of BHM-1 was oriented parallel to the bedding. The samples were immediately sealed in vacuum-evacuated aluminium foil after core extraction. Core samples were cut under dry conditions to a diameter-to-length ratio of approximately $2: 1$. Sample sections from $2.5-3.3 \mathrm{~m}$ depth (N specimens) and 8.5-9.4 m depth (P specimens) were selected. Both sections were located outside of the EDZ as no EDZrelated fractures were detected at these depths. Additionally, a cubic specimen (S4) was cut in such a way as to allow for the measurement of the principal strains (i.e. the strains perpendicular, $\varepsilon_{1}$, and parallel, $\varepsilon_{2}$, to the bedding plane orientation and the strain in the plane of isotropy, $\varepsilon_{3}$ ). The layout of the electric resistive strain gauges (HBM type: K-LY46) that were directly glued onto the specimen's faces is shown in Fig. 2a. Furthermore, one cylindrical specimen (E19) was used to measure the strain perpendicular and parallel to bedding (Fig. 2b). The environmental exposure time of the specimens during the installation of the strain gauges was minimized to about $30 \mathrm{~min}$.

\subsection{Experimental layout}

The specimens were exposed in desiccators to an alternating sequence of low and high RH levels under unstressed conditions. The RH was controlled by using supersaturated salt solutions. Sodium nitrite $\left(\mathrm{NaNO}_{2}, \mathrm{RH}=66 \%\right.$ at $\left.20^{\circ} \mathrm{C}\right)$ and ammonium di-hydrogen phosphate $\left(\mathrm{NH}_{4} \mathrm{H}_{2} \mathrm{PO}_{4}, \mathrm{RH}=93 \%\right.$ at $20^{\circ} \mathrm{C}$ ) were used based on the seasonal variations at the Mont Terri URL between 1997 and 2011 reported by Swisstopo (2014). It was found that the RH follows a cyclic annual variation following a sine curve with maximum humid- 


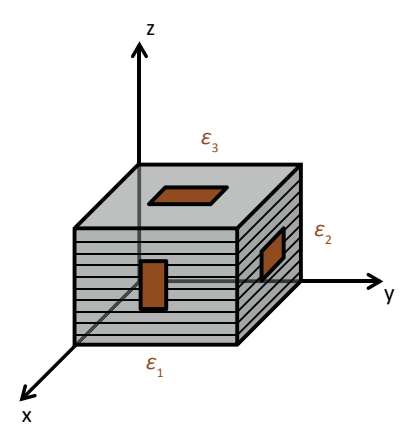

(a)

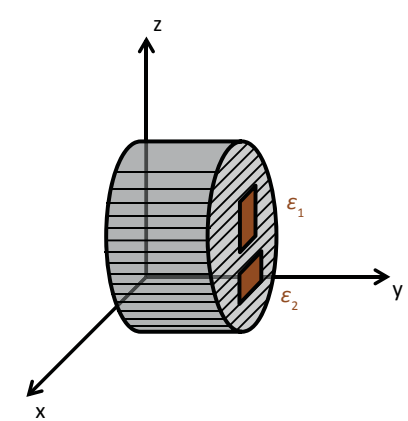

(b)

Figure 2. Illustration of strain gauge arrangement for measurements of principal strains: (a) on a cubic Opalinus Clay specimen (S4) measuring all principal strains individually; (b) on a cylindrical Brazilian test specimen (E19) measuring only two principal strains.

ity values of $93.8 \%$ during summer and minimum humidity values of $62.6 \%$ during winter. At each level of $\mathrm{RH}$, the specimens were allowed to equilibrate with the environment. Equilibration was achieved when the weight of the specimens (periodically measured every 1-7 days, accuracy $0.01 \mathrm{~g}$ ) remained constant. Homogeneity of the ambient conditions within the desiccator boxes was ensured by installing computer fans at the back of the boxes. Brazilian tensile strength tests were conducted after each cycle when the specimens were equilibrated at $66 \% \mathrm{RH}$. In total 4.5 cycles were applied, starting with an equilibration phase at $93 \%$ RH to establish the same initial conditions for all specimens. The experimental setup is schematically shown in Fig. 3. For the monitoring of the RH, a Honeywell HIH-4000-001 sensor (sampling rate of about $12 \mathrm{~h}$, accuracy $\pm 3.5 \%$ ) was used. Temperature was monitored by a resistance thermometer (Pt100) (sampling rate of about $12 \mathrm{~h}$, accuracy $0.015^{\circ} \mathrm{C}$ ). The temperature in the laboratory was kept between 19 and $23^{\circ} \mathrm{C}$ throughout the experiment.

\subsection{Suction and strain calculations}

The water content was determined according to the International Society for Rock Mechanics (ISRM)-suggested methods (ISRM, 1979). From the RH and the temperature that were monitored during the experiment, the total suction can be calculated according to Kelvin's relationship:

$\Psi=-\frac{R T}{V_{\mathrm{w} 0} \omega_{\mathrm{w}}} \ln \left(\frac{p}{p_{0}}\right)$,

where $\Psi$ is the suction in pascal, $R$ is the ideal gas constant (i.e. $8.314 \mathrm{~J} \mathrm{~mol}^{-1} \mathrm{~K}^{-1}$ ), $T$ the absolute temperature in kelvin, $V_{\mathrm{w} 0}$ the specific volume of water (i.e. about $0.001 \mathrm{~m}^{3} \mathrm{~kg}^{-1}$ ), $\omega_{\mathrm{w}}$ the molecular mass of water vapour (i.e. $\left.0.018 \mathrm{~kg} \mathrm{~mol}^{-1}\right), p$ the vapour pressure of water in the system in megapascal, and $p_{0}$ the vapour pressure of pure water in megapascal. The ratio $p / p_{0}$ equals the $\mathrm{RH}$.

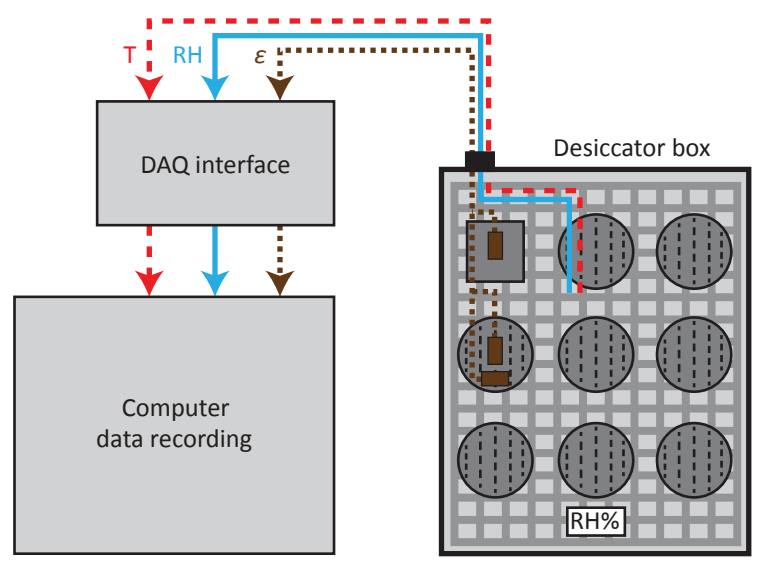

Figure 3. Schematic illustration of the experimental setup of the stepwise cyclic RH laboratory experiment.

On the cubic specimen (S4), strains were measured in all three principal directions. Thus, the volumetric strain $\left(\varepsilon_{\mathrm{v}}\right)$ can be calculated by adding all three principal strains (i.e. $\left.\varepsilon_{\mathrm{v}}=\varepsilon_{1}+\varepsilon_{2}+\varepsilon_{3}\right)$. On the cylindrical specimen (E19), the strain parallel $\left(\varepsilon_{2}\right)$ and perpendicular $\left(\varepsilon_{1}\right)$ to the bedding was recorded. Assuming a transversely isotropic material, the strain parallel to bedding $\left(\varepsilon_{2}\right)$ equals the strain in the plane of isotropy $\left(\varepsilon_{3}\right)$. Hence, the volumetric strain can be calculated from the sum of the strain perpendicular to bedding and twice the strain parallel to bedding (i.e. $\varepsilon_{\mathrm{v}}=\varepsilon_{1}+2 \varepsilon_{2}$ ). For all strains, expansion is taken as positive.

\subsection{Mechanical testing procedure}

Brazilian tensile strength tests were conducted at ETH Zurich utilizing a modified $2000 \mathrm{kN}$ servo-hydraulic rock-testing machine (Walter and Bai, Switzerland). The tests were conducted according to the ISRM-suggested methods (ISRM, 1978) immediately after removal from the desiccator. Load was applied parallel (P specimens) or normal to bedding (N specimens) (Fig. 4) using a constant loading rate of $0.08 \mathrm{kN} \mathrm{s}^{-1}$ (except for specimens N1-N6, for which a loading rate of $0.05 \mathrm{kN} \mathrm{s}^{-1}$ was used). The accuracy is $<1 \%$ of the actual reading.

\section{Results}

The specimens' dimensions and initial properties are given in Table 1. The initial water contents of the specimens range between 6.95 and $7.34 \%$, which is comparable with the water content measured on cores right after core extraction (Pearson et al., 2003; Amann et al., 2011; Wild, 2016). The initial saturation was estimated from the initial water content, the bulk dry density, and the porosity of the specimens according to the ISRM-suggested methods (ISRM, 1979). A grain density of $2.73 \mathrm{~g} \mathrm{~cm}^{-3}$ was used to calculate the porosity (Pearson et al., 2003; Bossart, 2005; own data). Values of 
Table 1. Properties and test configurations of specimens. Water content, dry density, porosity, and initial saturation were determined according to ISRM (1979). Furthermore, the direction of the applied load with respect to bedding during the Brazilian tensile strength tests is indicated.

\begin{tabular}{|c|c|c|c|c|c|c|c|}
\hline $\begin{array}{l}\text { Specimen } \\
\text { no. } \\
(-)\end{array}$ & $\begin{array}{l}\text { Diameter } \\
(\mathrm{mm})\end{array}$ & $\begin{array}{r}\text { Thickness } \\
(\mathrm{mm})\end{array}$ & $\begin{array}{r}\text { Initial water } \\
\text { content } \\
(\%)\end{array}$ & $\begin{array}{r}\text { Bulk dry } \\
\text { density } \\
\left(\mathrm{g} \mathrm{cm}^{-3}\right)\end{array}$ & $\begin{array}{r}\text { Porosity } \\
(\%)\end{array}$ & $\begin{array}{r}\text { Initial } \\
\text { saturation } \\
(\%)\end{array}$ & $\begin{array}{l}\text { Direction of } \\
\text { applied stress } \\
(-)\end{array}$ \\
\hline A1 & 67.32 & 35.35 & 6.95 & 2.30 & 15.85 & 100.8 & parallel \\
\hline $\mathrm{A} 2$ & 67.20 & 34.78 & 7.13 & 2.28 & 16.47 & 98.7 & parallel \\
\hline A3 & 67.66 & 34.70 & 7.33 & 2.26 & 17.10 & 97.0 & parallel \\
\hline A4 & 67.61 & 32.33 & 7.23 & 2.24 & 17.96 & 90.1 & parallel \\
\hline A5 & 67.64 & 35.76 & 7.02 & 2.27 & 16.69 & 95.7 & parallel \\
\hline A6 & 67.37 & 35.94 & 6.97 & 2.28 & 16.47 & 96.5 & parallel \\
\hline A7 & 67.59 & 34.49 & 7.04 & 2.28 & 16.49 & 97.3 & parallel \\
\hline A8 & 67.44 & 35.01 & 7.01 & 2.30 & 15.74 & 102.4 & parallel \\
\hline A9 & 67.39 & 35.27 & 7.34 & 2.26 & 17.09 & 97.2 & parallel \\
\hline A10 & 67.58 & 35.50 & 7.21 & 2.27 & 16.80 & 97.4 & parallel \\
\hline A11 & 67.52 & 34.77 & 7.20 & 2.28 & 16.33 & 100.7 & parallel \\
\hline A12 & 67.63 & 35.06 & 7.16 & 2.27 & 16.96 & 95.7 & parallel \\
\hline A14 & 67.54 & 35.16 & 7.26 & 2.26 & 17.29 & 94.8 & parallel \\
\hline A 15 & 67.51 & 34.89 & 7.27 & 2.27 & 17.02 & 96.8 & parallel \\
\hline E1 & 67.06 & 36.47 & 7.23 & 2.30 & 15.59 & 106.9 & normal \\
\hline E2 & 67.12 & 34.51 & 7.24 & 2.28 & 16.35 & 101.1 & normal \\
\hline E3 & 67.08 & 35.17 & 7.25 & 2.30 & 15.74 & 105.9 & normal \\
\hline E4 & 67.1 & 35.18 & 7.14 & 2.30 & 15.82 & 103.7 & normal \\
\hline E6 & 67.14 & 34.79 & 7.21 & 2.30 & 15.85 & 104.5 & normal \\
\hline E7 & 67.02 & 35.74 & 7.13 & 2.29 & 15.97 & 102.4 & normal \\
\hline E8 & 67.15 & 35.06 & 7.07 & 2.29 & 16.15 & 100.2 & normal \\
\hline E9 & 67.21 & 35.64 & 7.12 & 2.28 & 16.42 & 98.9 & normal \\
\hline E10 & 67.24 & 35.17 & 7.10 & 2.28 & 16.62 & 97.3 & normal \\
\hline E11 & 67.47 & 35.07 & 7.23 & 2.26 & 17.29 & 94.4 & normal \\
\hline E12 & 67.43 & 34.98 & 7.15 & 2.27 & 16.79 & 96.8 & normal \\
\hline E13 & 67.56 & 36.08 & 7.19 & 2.24 & 18.08 & 88.9 & normal \\
\hline E14 & 67.50 & 36.06 & 7.16 & 2.27 & 16.73 & 97.2 & normal \\
\hline E15 & 67.20 & 35.78 & 7.15 & 2.28 & 16.65 & 97.7 & normal \\
\hline E16 & 67.08 & 34.23 & 7.06 & 2.28 & 16.41 & 98.1 & normal \\
\hline E17 & 67.28 & 35.40 & 7.04 & 2.28 & 16.57 & 96.7 & normal \\
\hline E18 & 67.25 & 35.26 & 7.05 & 2.27 & 16.73 & 95.8 & normal \\
\hline
\end{tabular}

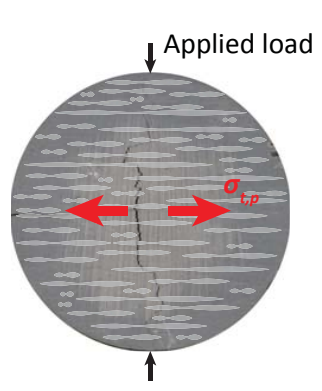

(a)

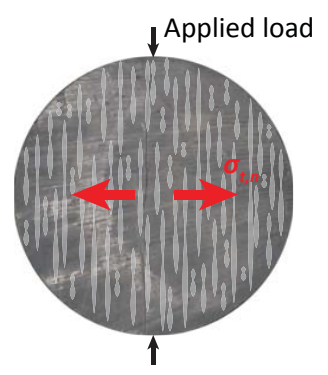

(b)
Figure 4. Loading configuration for the Brazilian tests with respect to bedding (bedding orientation is indicated by the light grey pattern). In panel (a) the load is applied normal to bedding, allowing the measurement of the Brazilian tensile strength parallel to bedding $\left(\sigma_{t, p}\right)$. In panel (b) the load is applied parallel to bedding, allowing the measurement of the Brazilian tensile strength normal to bedding $\left(\sigma_{\mathrm{t}, \mathrm{n}}\right)$. saturation that exceed $100 \%$ can be related to the uncertainty in the grain density $\left( \pm 0.03 \mathrm{~g} \mathrm{~cm}^{-3}\right)$ and the specimen's volume.

Figure 5 shows the results of the $\mathrm{RH}$, temperature, and strain measurements for the $\mathrm{N}$ specimens. The specimens were first equilibrated to a $\mathrm{RH}$ of $93 \%$ and then subjected to 4.5 cycles with peak-peak amplitudes of between 30 and $36 \%$ (i.e. RH variation between 63 and $94 \%$; Fig. 5a). The resulting suction applied to the specimens was calculated according to Eq. (1) and is plotted together with the corresponding response of the water content in Fig. 5b. Similar trends with respect to the water content changes were observed for all specimens. A constant water content and a small change in volumetric strain were observed during the first equilibration phase, indicating a high initial saturation degree of the specimens. During cycling, the water content changed by $\pm 2.2-2.4 \%$. Except for the first drying period, in which $0.6-0.8 \%$ water content was lost, the water con- 


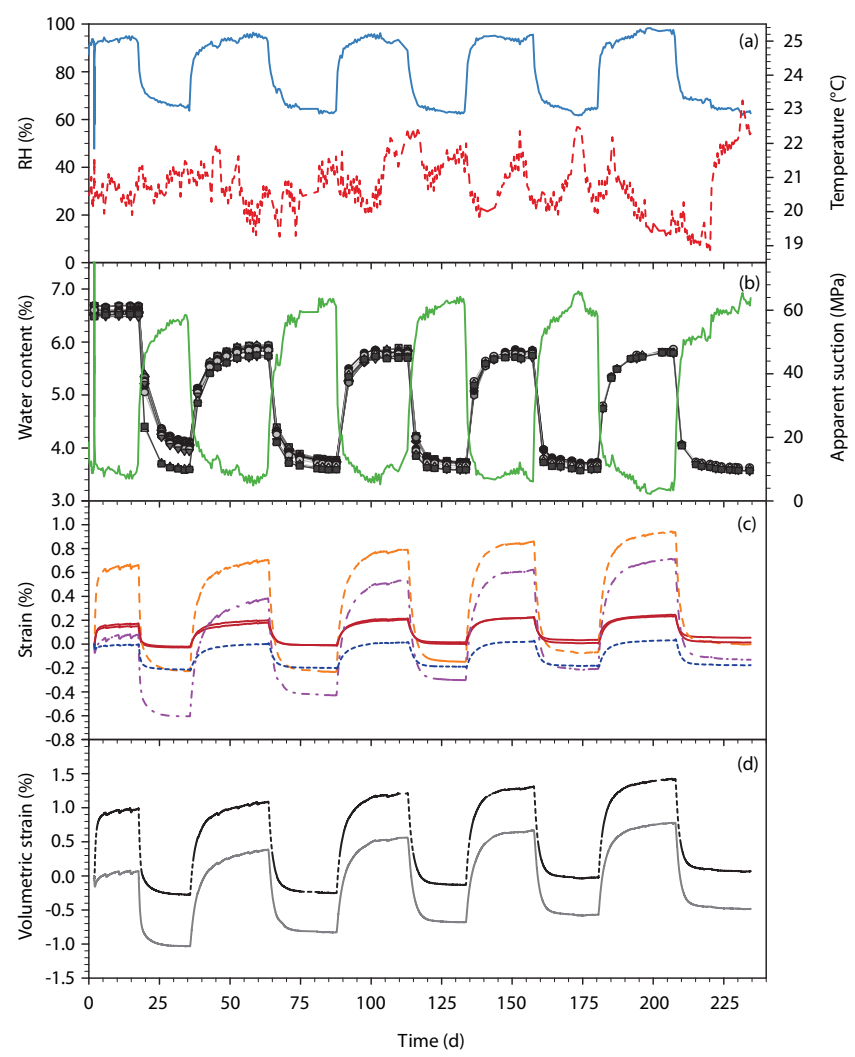

\begin{tabular}{|c|c|c|c|c|c|}
\hline \multirow{7}{*}{$\overline{---}$} & \multirow{7}{*}{$\begin{array}{l}\text { RH (measured) } \\
\text { Temperature } \\
\text { Apparent suction }\end{array}$} & \multicolumn{3}{|c|}{ Water content } & \multirow{7}{*}{ 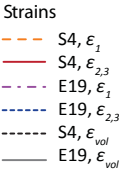 } \\
\hline & & $\multimap \mathrm{N} 1$ & $\diamond \quad N 9$ & $\nabla \mathrm{N} 16$ & \\
\hline & & $\therefore \quad N 2$ & $\triangle \mathrm{N} 10$ & $\begin{array}{ll}\Delta \quad \mathrm{N} 17\end{array}$ & \\
\hline & & $\rightarrow \mathrm{N} 3$ & $\begin{array}{ll}\nabla & \mathrm{N} 11\end{array}$ & $\rightarrow-\mathrm{N} 18$ & \\
\hline & & $\begin{array}{cc}\Delta & N 4 \\
- & N 6\end{array}$ & $\longrightarrow \mathrm{N} 12$ & & \\
\hline & & $\because \quad$ N7 & $\because \quad \mathrm{N} 14$ & & \\
\hline & & $\longrightarrow \mathrm{N} 8$ & $-\mathrm{N} 15$ & & \\
\hline
\end{tabular}

Figure 5. Results of the stepwise cyclic RH experiment for the $\mathrm{N}$ specimens, including (a) the changes in relative humidity $(\mathrm{RH})$ and temperature, (b) the water content and apparent suction calculated from the measured $\mathrm{RH}$, (c) the principal strains normal to bedding $\left(\varepsilon_{1}\right)$ and parallel to bedding $\left(\varepsilon_{2}\right.$ and $\left.\varepsilon_{3}\right)$ of specimens S4 and E19, and (d) the volumetric strains of specimens S4 and E19.

tent was reversible. A comparable response was observed for the series of $\mathrm{P}$ specimens (Fig. 6) which were subjected to the same testing procedure, although RH or strains were not measured explicitly. Strain measurements on the specimens E19 and S4 showed an immediate response to changes in RH (Fig. 5c, d). Swelling occurred during wetting, shrinkage during drying phases. The magnitude of swelling exceeded the shrinkage, which accumulated to an irreversible volumetric strain of $0.55-0.75 \%$ at the end of the experiment (Fig. 5d). The individual strain measurements showed that mainly deformations normal to bedding contributed to the overall expansion of the rock specimen. The strain measured parallel to bedding was significantly smaller and approximately reversible.

Although irreversible strain was measured, no significant change in Brazilian tensile strength was observed (Fig. 7).

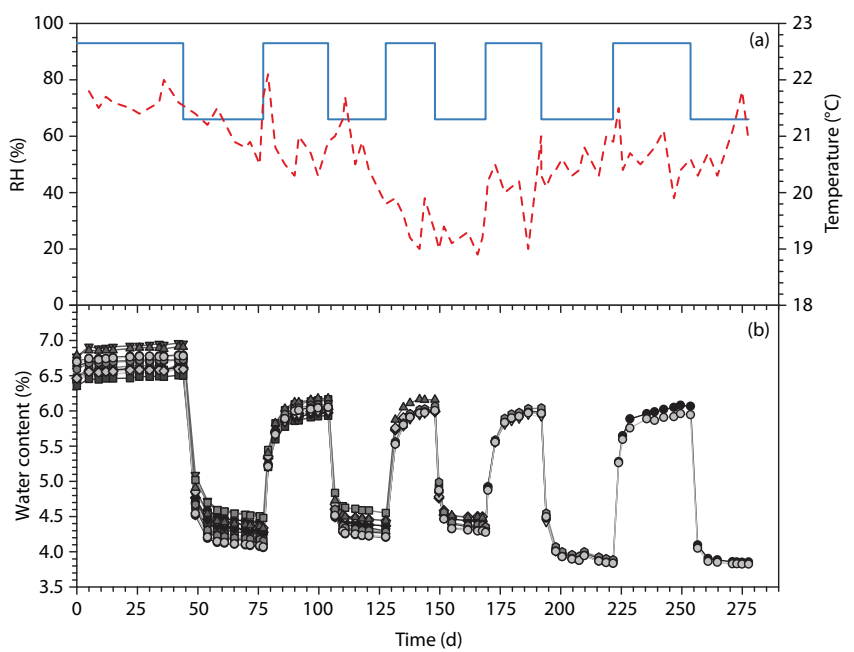

\begin{tabular}{|c|c|c|c|c|c|c|c|}
\hline \multirow{5}{*}{ - - } & \multirow{3}{*}{$\begin{array}{l}\text { RH (theoretical) } \\
\text { Temperature }\end{array}$} & \multicolumn{6}{|c|}{ Water content } \\
\hline & & $\rightarrow$ & P1 & $\rightarrow P 5$ & $\triangle-$ & P9 & $\rightarrow \mathrm{P} 14$ \\
\hline & & 0 & P2 & $\rightarrow-P 6$ & $\nabla$ & P10 & - P15 \\
\hline & & $\rightarrow$ & P3 & $\because$ P7 & 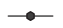 & P11 & \\
\hline & & $\Delta$ & P4 & $\diamond \quad P 8$ & 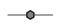 & P12 & \\
\hline
\end{tabular}

Figure 6. Results of the stepwise cyclic RH experiment for the $\mathrm{P}$ specimens, including (a) the theoretically applied levels of relative humidity (RH) and the measured temperature (in the laboratory) and (b) the water content of the specimens.

The Brazilian tensile strength parallel to bedding remained constant over three to five cycles, while corresponding values for the direction normal to bedding only indicate insignificant decreasing trends that lie within the strength values reported by Wild et al. (2015) for specimens that were equilibrated to 56-87 MPa suction. Thus, a change in Brazilian tensile strength as a response to the RH variations was not measurable or insignificant.

\section{Discussion}

\subsection{Water retention}

Figure 8 shows the relationship between suction and water content for specimen E7 during the stepwise cyclic RH experiment. The system is in equilibrium at the highest and lowest suction values (turning points between wetting and drying paths) but not in between. Also shown are the main drying and wetting paths reported by Wild et al. (2015).

The first drying path for the specimen follows the main drying path as it represents the drying of the intact rock starting from initial conditions which were comparable to the study of Wild et al. (2015). Since the specimens were not dried to their residual water content, the following scanning curves lie between the main drying and main wetting paths. Hysteresis can be observed between drying and wetting path caused by non-homogeneous pore size distribution, different contact angles between wetting and drying, or entrapped 


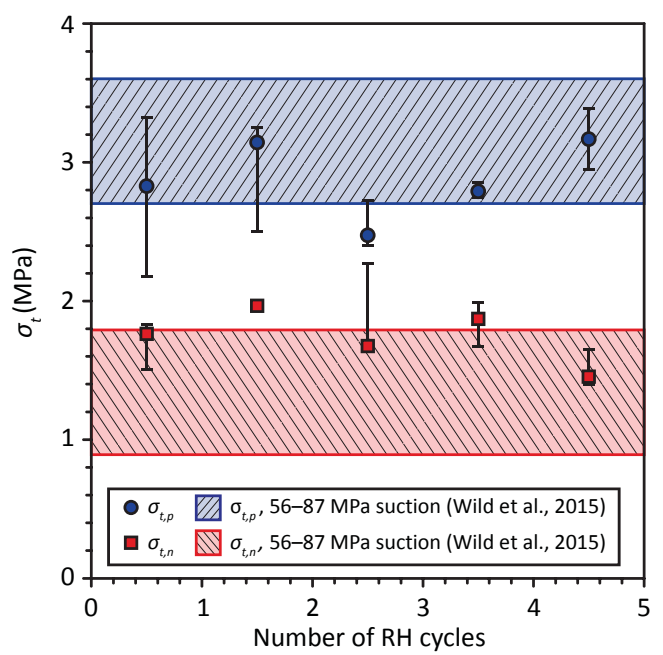

Figure 7. The median value and the associated ranges of the Brazilian tensile strength of specimens from the stepwise cyclic RH experiment with tension parallel $\left(\sigma_{t, p}\right)$ and normal $\left(\sigma_{t, n}\right)$ to bedding. Furthermore, the range of Brazilian tensile strength values reported by Wild et al. (2015) for specimens that were equilibrated to 56$87 \mathrm{MPa}$ suction are indicated.

air bubbles during wetting (Birle et al., 2008). Therefore, the initial water content cannot be re-established anymore and a water loss of $0.6-0.8 \%$ occurred. However, the scanning curves of the specimen subjected to the stepwise RH cycles approximately lie within the main drying and wetting paths, indicating that the water retention characteristics are not significantly affected by the variations in RH. This is consistent with findings by Pineda et al. (2014).

\subsection{Strain and damage}

Strain results of the dynamic and stepwise cyclic RH experiments (Fig. 5c) indicate that the Opalinus Clay follows a cyclic expansion and contraction associated with water absorption and desorption processes. Thereby, the Opalinus Clay shows a strongly transversely isotropic deformation behaviour where the strain in the direction normal to bedding $\left(\varepsilon_{1}\right)$ dominates the bulk deformation. These results are consistent with findings by Minardi et al. (2016), who also found an anisotropic response of strain for an Opalinus Clay specimen subjected to one cycle of wetting and drying. This observation can be related to the absorption of water into parallelorientated clay interlayers (i.e. parallel to the bedding planes) leading to swelling in normal direction. Moreover, according to Houben et al. (2013), the pores of Opalinus Clay are elongated along the bedding.

Irreversible volumetric expansion took place during the stepwise cyclic RH exposure. Many studies on single mineral types (e.g. Na-montmorillonite) have demonstrated that clay minerals show distinct hydration states when exposed to different levels of RH (e.g. Mering, 1946; Mooney et

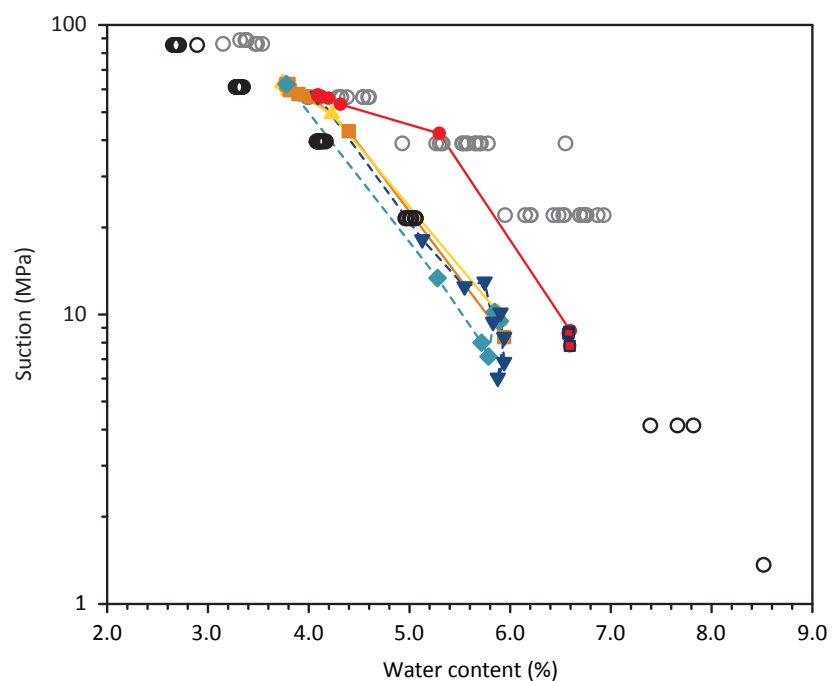

\begin{tabular}{|c|c|c|}
\hline -七- Equilibration at $93 \%$ & $\rightarrow-$ & 2nd drying \\
\hline$-\nabla-1$ st wetting & $\rightarrow-$ & 3rd drying \\
\hline$-\curvearrowleft-2$ nd wetting & 0 & Main drying (Wild et al. 2015) \\
\hline$\rightarrow$ 1st drying & 0 & Main wetting (Wild et al. 2015) \\
\hline
\end{tabular}

Figure 8. Water retention curve for specimen N7 displaying suction as a function of the water content. Also shown are the water retention curves (main drying and main wetting) reported by Wild et al. (2015) for specimens which were equilibrated to the applied level of RH at any point.

al., 1952; Gillery, 1959; Emerson, 1962; Van Olphen, 1965; Glaeser and Mering, 1968; Chipera et al., 1997; Ferrage et al., 2005; Likos and Lu, 2006). These hydration stages reflect the intercalation of one to four discrete layers of water molecules between the mineral interfaces and are driven by the hydration of the cations of the clay minerals (Norrish, 1972). During transition between these stages, the interlayer spacing can increase by up to a factor of 2 (Norrish, 1954). For the hydration of Na-montmorillonite, for example, the interlayer spacing increases from 10 to $12.5 \AA$ between 0 and $20 \% \mathrm{RH}$, from 12.5 to $15.5 \AA$ between 50 and $70 \%$ RH, and further to about $19 \AA$ for RH $>98.5 \%$ (Mooney et al., 1952; Gillery, 1959; Emerson, 1962; Glaeser and Mering, 1968). Between 70 and $95 \%$ a two-layer hydration state is present for both $\mathrm{Ca}$ - and Na-montmorillonite (Seedsman, 1985). Similar stages for other clay minerals are given by Gillery (1959). They all indicate a relatively stable state between 80 and $90 \%$ RH. Furthermore, sorption and adsorption paths for clay minerals show hysteresis, indicating that crystalline swelling is an irreversible thermodynamic process (Laird et al., 1995).

This might explain the accumulated irreversible volumetric expansion as most of the clay minerals transition between the one- and two-layer hydration state in the RH range covered within the experiments in this study. This is also supported by macroscopically detectable cracking that was observed during the experiment. 
Although slight cracking of the specimens was detected and irreversible volumetric strain was observed, no significant influence on the Brazilian tensile strength was observed after three to five cycles for both experiments. It is therefore concluded that the observed degradation caused by the cyclic variations of RH in this study is not sufficient to cause severe damage that influences the strength of the material. The lower degradation potential for Opalinus Clay compared to other clay shales when subjected to RH cycling is in agreement with findings reported by Pineda et al. (2011). Compared to Lilla Claystone (Pineda et al., 2008, 2014), the (tensile) strength and (dynamic) stiffness of Opalinus Clay is significantly less affected by cyclic RH variations.

\section{Conclusions}

This study demonstrates that cyclic $\mathrm{RH}$ variations have the potential to internally damage the Opalinus Clay leading to irreversible volumetric expansion. Internal damage mainly takes place along the bedding, supported by the fact that irreversible strain was almost exclusively observed in the direction normal to the bedding.

The Brazilian tensile strength of Opalinus Clay seems to be unaffected by cyclic RH variations (i.e. a change was not measurable or insignificant). The Brazilian tensile strength parallel to bedding remained constant over three to five cycles while corresponding values for the direction normal to bedding only indicate insignificant decreasing trends. Water retention characteristics of Opalinus Clay were not significantly altered by the observed environmental degradation.

The experimental study demonstrates that $\mathrm{RH}$ variations can lead to irreversible volumetric strains and therefore supports the hypothesis that long-term environmental variations might contribute to long-term deformations of underground excavations and favour processes that are considered to control self-sealing in Opalinus Clay.

Data availability. The data of this study can be provided by the authors upon request.

Author contributions. The experiment was carried out by Patric Walter under the supervision of Florian Amann and Katrin M. Wild. Katrin M. Wild prepared the paper with contributions from all co-authors.

Competing interests. The authors declare that they have no conflict of interest.

Acknowledgements. This study was funded by the Swiss Federal Nuclear Safety Inspectorate ENSI. The authors would like to thank Reto Seifert and Stewart Bishop (ETH Zurich) for their support with the mechanical and electrical challenges during the setup of the experiment. We are also grateful to Matthew Perras and Wilfried Winkler (ETH Zurich) for fruitful discussions. Furthermore, we would like to thank Claudio Madonna (ETH Zurich) for help provided during the laboratory work and for feedback on this paper.

Edited by: M. Oliva

Reviewed by: two anonymous referees

\section{References}

Al-Homoud, A. S., Basma, A. A., Husein Malkawi, A. I., and Al Bashabsheh, M. A.: Cyclic Swelling Behavior of Clays, J. Geotech. Eng., 121, 562-565, 1995.

Amann, F., Button, E. A., Evans, K. F., Gischig, V. S., and Blümel, M.: Experimental study of the brittle behavior of clay shale in rapid unconfined compression, Rock Mech. Rock Eng., 44, 415430, 2011.

Amann, F., Kaiser, P. K., and Button, E. A.: Experimental study of the brittle behavior of clay shale in rapid triaxial compression, Rock Mech. Rock Eng., 45, 21-33, 2012.

Basma, A. A., Al-Homoud, A. S., Husein Malkawi, A. I., and AlBashabsheh, M. A.: Swelling-shrinkage behavior of natural expansive clays, Appl. Clay Sci., 11, 211-227, 1996.

Bernier, F., Li, X. L., Bastiaens, W., Ortiz, L., Van Geet, M., Wouters, L., Fireg, B., Blümling, P., Desrues, J., Viaggiani, G., Coll, C., Chanchole, S., De Greef, V., Hamza, R., Malinsky, L., Vervoort, A., Vanbrabant, Y., Debecker, B., Verstraelen, J., Govaerts, A., Wevers, M., Labiouse, V., Escoffier, S., Mathier, J.-F. Gastaldo, L., and Bühler, Ch.: Fracture and Self-healing within the excavation Disturbed Zone in Clays (SELFRAC), Final report, European Commission Report, Luxembourg, EUR 22585, 62 pp., 2007.

BFE (Bundesamt für Energie): Press Release 01.12.2011, Bern, Switzerland, 2011.

Birle, E., Heyer, D., and Vogt, N.: Influence of the initial water content and dry density on the soil-water retention curve and the shrinkage behavior of a compacted clay, Acta Geotech., 3, 191200, 2008.

Bossart, P.: Characteristics of Opalinus Clay at Mont Terri, available at: http://www.mont-terri.ch/internet/mont-terri/de/home/ geology/key_characteristics.html (last access: 11 July 2016), 2005.

Cardoso, R., Della Vecchia, G., Jommi, C., and Romero, E.: Water retention curve for evolving marl under suction cycles, in: Unsaturated Soils, edited by: Alonso, E. and Gens, A., Proceedings of the 5th International Conference on Unsaturated Soils, 6-8 September 2010, Barcelona, Spain, 2, 1451-1457, 2011.

Chen, F. H. and Ma, G. S.: Swelling and Shrinkage Behavior of Expansive Clays, in: Proceedings of the 6th International Conference on Expansive Soils, 1-4 December 1987, New Delhi, India, 127-129, 1987.

Chipera, S. J., Carey, J. W., and Bish, D. L.: Controlled-humidity XRD analyses: Application to the study of smectite expansion/contraction, Adv. X Ray Anal., 39, 713-722, 1997.

Chu, T. Y. and Mou, C. H.: Volume change characteristics of expansive soils determined by con-trolled suction tests, in: Proceedings 
of the 3rd International Conference on Expansive Soils, 30 July1 August 1973, Haifa, Israel, 2, 177-185, 1973.

Day, R. W.: Swell-shrink behavior of compacted clay, J. Geotech. Eng., 120, 618-623, 1994.

Dif, A. E. and Bluemel, W. F.: Expansive Soils under Cyclic Drying and Wetting, Geotech. Test. J., 14, 96-102, 1991.

Emerson, W. W.: The swelling of Ca-montmorillonite due to water absorption, 1. Water uptake in the vapour phase, J. Soil Sci., 13, 31-39, 1962.

Farulla, C. A., Ferrari, A., and Romero, E.: Volume change behaviour of a compacted scaly clay during cyclic suction changes, Can. Geotech. J., 47, 688-703, 2010.

Ferrage, E., Lanson, B., Sakharov, B. A., and Drits, V. A.: Investigation of smectite hydration properties by modeling experimental X-ray diffraction patterns: Part I. Montmorillonite hydration properties, Am. Mineral., 90, 1358-1374, 2005.

Gillery, F. H.: Adsorption-desorption characteristics of synthetic montmorillonoids in humid atmospheres, Am. Mineral., 44, 806$818,1959$.

Glaeser, R. and Mering, J.: Homogeneous hydration domains of the smectites, Cr. Acad. Sci. D Nat., 267, 463-466, 1968.

Grice, R. H.: The Effect of Temperature-Humidity on the Disintegration of Nonexpandable Shales, Bull. Asso Eng. Geol., 5, 7077, 1968.

Houben, M. E., Desbois, G., and Urai, J. L.: Pore morphology and distribution in the Shaly facies of Opalinus Clay (Mont Terri, Switzerland): Insights from representative 2D BIB-SEM investigations on mm to nm scale, Appl. Clay Sci., 71, 82-97, 2013.

ISRM: Suggested Methods for Determining Tensile Strength of Rock Materials, Int. J. Rock Mech. Min., 15, 99-103, 1978.

ISRM: Suggested Methods for Determining Water Content, Porosity, Density, Absorption and Related Properties and Swelling and Slake-Durability Index Properties, Int. J. Rock Mech. Min., 16, 141-156, 1979.

Klinkenberg, M., Kaufhold, S., Dohrmann, R., and Siegesmund, S.: Influence of carbonate micro-fabrics on the failure strength of claystones, Eng. Geol., 107, 42-54, 2009.

Laird, D.A., Shang, C., and Thompson, M.L.: Hysteresis in Crystalline Swelling of Smectites, J. Colloid Interf. Sci., 171, 240245, 1995.

Likos, W. J. and Lu, N.: Pore-scale analysis of bulk volume change from crystalline interlayer swelling in $\mathrm{Na}^{+}-$and $\mathrm{Ca}_{2}^{+}$-smectite, Clay Clay Miner., 54, 515-528, 2006.

Marschall, P., Croisé, J., Schlickenrieder, L., Boisson, J.-Y., Vogel, P., and Yamamoto, S.: Synthesis of Hydrogeological Investigations at Mont Terri Site (Phase 1 to 5), in: Mont Terri Project - Hydrogeological Synthesis, Osmotic Flow, edited by: Heitzmann, P., Reports of the Federal Office for Water and Geology, Geology Series, 6, 7-92, 2004.

Mazurek, M.: Mineralogical composition of Opalinus Clay at Mont Terri - a laboratory inter-comparison, unpublished Mont Terri Technical Note TN 98-41, 1998.

Mazurek, M., Hurford, A. J., and Leu, W.: Unravelling the multistage burial history of the Swiss Molasse Basin: integration of apatite fission track, vitrinite reflectance and biomarker isomerisation analysis, Basin Res., 18, 27-50, 2006.

Mering, J.: On the hydration of montmorillonite, T. Faraday Soc., 42, 205-219, 1946.
Minardi, A., Crisci, E., Ferrari, A., and Laloui, L.: Anisotropic volumetric behaviour of Opalinus Clay shale upon suction variation, Géotechnique Letters, 6, 144-148, 2016.

Mooney, R. W., Keenan, A. G., and Wood, L. A.: Adsorption of Water Vapor by Montmorillonite. II. Effect of Exchangeable Ions and Lattice Swelling as Measured by X-Ray Diffraction, J. Am. Chem. Soc., 74, 1371-1374, 1952.

Möri, A., Bossart, P., Matray, J.-M., Müller, H., and Frank, E.: Mont Terri project, cyclic deformations in the Opalinus Clay, in: ANDRA, Clays in Natural \& Engineered Barriers for Radioactive Waste Confinement, 4th International Meeting, 29 March1 April 2010, Nantes, France, 81-82, 2010.

Nagra: Projekt Opalinuston. Synthese der geowissenschaftlichen Untersuchungsergebnisse, Nagra Technischer Bericht NTB 0203, Wettingen, Switzerland, 2002.

Norrish, K.: The Swelling of Montmorillonite, T. Faraday Soc., 18, 120-134, 1954.

Norrish, K.: Forces between clay particles, in: Proceedings of the International Clay Conference, edited by: Serratosa, J. M. and Sanchez, A., 23-30 June 1972, Madrid, Spain, 1, 375-383, 1972.

Nussbaum, C., Bossart, P., Amann, F., and Aubourg, C.: Analysis of tectonic structures and excavation induced fractures in Opalinus Clay, Mont Terri underground rock laboratory (Switzerland), Swiss J. Geosci., 104, 187-210, 2011.

Olivier, H. J.: Some aspects of the influence of mineralogy and moisture redistribution on the weathering behavior of mudrocks, in: Proceedings of the 4th ISRM Congress, 2-8 September 1979, Montreux, Switzerland, 467-474, 1979.

Osipov, V. I., Bik, N. G., and Rumjantseva, N. A.: Cyclic Swelling of Clays, Appl. Clay Sci., 2, 363-374, 1987.

Pearson, F. J., Arcos, D., Bath, A., Boisson, J.-Y., Fernández, A. M., Gäbler, H.-E., Gautschi, A., Griffault, L., Hernán, P., and Waber, H. N.: Mont Terri Project - Geochemistry of Water in the Opalinus Clay Formation at the Mont Terri Rock Laboratory, Reports of the Federal Office for Water and Geology (FOWG), Bern, Switzerland, 5, 321 pp., 2003.

Pejon, O. J. and Zuquette, L. V.: Analysis of cyclic swelling of mudrocks, Eng. Geol., 67, 97-108, 2002.

Pham, Q. T., Vales, F., Malinsky, L., Nguyen Minh, D., and Gharbi, H.: Effects of desaturation-resaturation on mudstone, Phys. Chem. Earth, 32, 646-655, 2007.

Pineda, J. A., Arroyo, M., Romero, E., and Alonso, E. E.: Dynamic tracking of hydraulically induced claystone degradation, in: Deformational Characteristics of Geomaterials, edited by: Burns, S. E., Mayne, P. W., and Santamarina, C. J., Proceedings of the 4th International Symposium on Deformation Characteristics of Geomaterials, 22-24 September 2008, Atlanta, Georgia, USA, 2, 809-816, 2008.

Pineda, J. A., Mitaritonna, G., Romero, E., and Arroyo, M.: Effects of hydraulic cycling on the stiff-ness response of a rigid clay, in: Unsaturated Soils, edited by: Alonso, E. and Gens, A., Proceedings of the 5th International Conference on Unsaturated Soils, 6-8 September 2010, Barcelona, Spain, 2, 1465-1470, 2011.

Pineda, J. A., Alonso, E. E., and Romero, E.: Environmental degradation of claystones, Géotechnique, 64, 64-82, 2014.

Popescu, M.: Behaviour of expansive soils with a crumb structure, in: Proceedings of the 4th International Conference on Expansive Soils, edited by: Snethen, D., 16-18 June 1980, Denver, Colorado, USA, 1, 158-171, 1980. 
Seedsman, R.: The behavior of clay shales in water, Can. Geotech. J., 23, 18-22, 1985.

Swisstopo (Bundesamt für Landestopographie): Relative humidity data at Mont Terri rock laboratory. Data acquisition Swisstopo, Mont Terri project, St-Ursanne, Switzerland, 2014.

Thury, M. and Bossart, P.: The Mont Terri rock laboratory, a new international research project in a Mesozoic shale formation, in Switzerland, Eng. Geol., 52, 347-359, 1999.

Tsang, C. F., Barnichon, J. D., Birkholzer, J., Li, X. L., Liu, H. H., and Sillen, X.: Coupled thermo-hydro-mechanical processes in the near field of a high-level radioactive waste repository in clay formations, Int. J. Rock Mech. Min., 49, 31-44, 2012.

Van Eeckhout, E. M.: The Mechanisms of Strength Reduction due to Moisture in Coal Mine Shales, Int. J. Rock Mech. Min., 13, 61-67, 1976.

Van Olphen, H.: Thermodynamics of interlayer adsorption of water in clays. I. Sodium Vermiculite, J. Colloid Sci., 20, 822-837, 1965.
Wild, K. M.: Evaluation of the hydro-mechanical properties and behavior of Opalinus Clay, Dissertation, ETH Zurich, Switzerland, 222 pp., 2016.

Wild, K. M., Wymann, L. P. Zimmer, S., Thoeny, R., and Amann, F.: Water Retention Characteristics and State-Dependent Mechanical and Petro-Physical Properties of a Clay Shale, Rock Mech Rock Eng., 48, 427-439, 2015.

Yang, D. S., Bornert, M., Chanchole, S., Charbi, H., Valli, P., and Gatmiri, B.: Dependence of elastic properties of argillaceous rocks on moisture content investigated with optical full-field strain measurement techniques, Int. J. Rock Mech. Min., 53, 4555,2012 